\section{One land and three narratives: Palestinian sites of memory in Israel}

Memory Studies 2018, Vol. II(3) 287-300

(C) The Author(s) 2018

Reprints and permissions: sagepub.co.uk/journalsPermissions.nav DOI: $10.1177 / 1750698018771859$ journals.sagepub.com/home/mss

@SAGE

\author{
Aleida Assmann \\ University of Konstanz, Germany
}

\begin{abstract}
The first part of the article invites a fresh look at the often defined concepts of 'space' and 'place', connecting them to different subject positions, mental frames and projects. The second part addresses memory issues that underlie the political conflict between the state of Israel and Palestinians in the Near East. It will analyse two seemingly incompatible memories related to the same events and topography. The focus of the essay is not only on the divisive force with which two incompatible histories are constructed in the same landscape but also on recent memory practices and performances that raise awareness of this impasse and work towards a more complex and inclusive transnational memory of the entangled history of 1948.
\end{abstract}

\title{
Keywords
}

conflict, forgetting, Holocaust, Nakba, national narrative, trauma

Memory clings to places as history to events.

(Pierre Nora)

'Great is the power of memory that resides in places' (Cicero, 1931, V. 1-2: 394-396). More recently, historian Karl Schlögel emphasized that places are an irreducible part of events: 'All our knowledge of history is attached to places. ... We cannot do without images of the sites where the events have happened: History takes place' (Schlögel, 2003: 64; trans. AA). Historic sites with or without material remains can serve as legible symbolic markers - they help us imagine and remember what is no longer there. This perspective opens up a number of important but difficult questions: how does history materialize within a national territory? How is it inscribed, anchored, erased, contested, transformed and renewed in urban and rural space? And who decides and controls what is remembered and what is forgotten in specific places? In order to frame these issues, I will start with a few theoretical reflections on the terms 'space' and 'place'.

\section{'Space' and 'place'}

The 'spatial turn' introduced new concepts and issues into cultural studies. A strong voice was that of Edward Soja, political geographer and urban planner, who since the late 1980s argued for the

\section{Corresponding author:}

Aleida Assmann, University of Konstanz, Egger Wiese I3, D. 78464 Konstanz, Germany.

Email: aleida.assmann@uni-konstanz.de 
new paradigm of space that was to replace the great obsession with time that had preoccupied historians since the nineteenth century. His claim was that space as the dimension of heterogeneous and simultaneous coexistence had been silenced by the overemphasis on linear temporal change. He drew attention to what had been forgotten in the nineteenth-century obsession with history and time, namely 'the life-world as being creatively located not only in the making of history but also in the construction of human geographies, the social production of space and the restless formation and reformation of geographical landscapes' (Soja, 1989: 10). In the 1960s, Foucault (1986) had already anticipated not only the spatial turn but also our digital reality when he argued that

we are in the epoch of simultaneity: we are in the epoch of juxtaposition, the epoch of the near and far, of the side-by-side, of the dispersed. We are at a moment, I believe, when our experience of the world is less that of a long life developing through time than that of a network that connects points and intersects with its own skein. (p. 22)

Space, as we have learned from social constructivists, is never merely a physical reality but the object of human activities, evaluations and transformations, be they historical, political or economic. Edward Said (2000) made the point that 'geography can be manipulated, invented, characterized quite apart from a site's merely physical reality' (p. 180). We no longer need to subscribe, however, to the opposition 'space versus time'. Instead, I want to show that time is always already involved when dealing with human geography. For this reason, I want to (re-)introduce the two terms 'space' and 'place' and focus on their inherent temporalities.

In a political and especially in a colonial context, the conquest of space is the central aim of power, with space conceived 'as something usable, malleable, and therefore capable of domination through human action' (Harvey, 1989: 176). In such a context, the term space is closely aligned with territory and calls for very specific forms of action; it is to be conquered or defended, discovered, traversed, colonized, measured, mapped, occupied. Space, indeed, is the central motor behind colonialism and modern geopolitics. It is to be transformed and exploited as the central locus, manifestation and symbol of power. But space is also a neutral and abstract term in the context of architects whose aim and profession is to usher in a new future by reconstructing and redesigning it. Their vision is guided by the notion of space as a tabula rasa for new styles, functions and aesthetic innovations.

The corresponding term 'place', on the contrary, refers to the specificity of concrete places that have become the focus of attention and various forms of topographical enquiry. Places in this sense can be defined as a condensation of historical events, as a thickening and materialization of history, as tangible carriers of signs and traces, which are eventually destroyed or preserved, discarded or deciphered, marked or unmarked, forgotten or remembered (Bachelard, 1994 [1958]; Tuan, 1977). It is the stage after some notable or violent action in the past has remained present, be it in material traces, be it in memory. The concept of 'place' became relevant when the focus of the modern time regime shifted from an exclusive orientation towards the future to the past and to ways of experiencing and remembering historical events. Together with this shift in temporal orientation, 'place' became a new object of historical interest that complements and transcends written and verbal sources. It applies the notion of legibility to landscapes, cities and places, without disregarding 'the fatal intersection of time with space' (Foucault, 1986: 22). Places, in other words, have an unmistakable profile, as they are saturated with history and linked to memory. In this respect, they are the opposite of so-called 'non-places' such as international airports and hotel-chains.

When I distinguish between 'space' and 'place', I have no intention of resurrecting yet another essentializing dichotomy. Instead, I want to draw attention to the different perspectives, strategies, conflicting interests and operative agendas already inherent in the language that is used. 'Space' in practical contexts is conceived as something to be shaped and transformed not only by generals, 
colonial officers and politicians who use weapons to establish power and create territories with maps and borders but also by architects and investors who use capital and have a mandate to peacefully transform human geographies according to their visions. 'Place', on the contrary, is a term used by inhabitants of cities, preservationists and the tourism industry, where it is conceived as something that is already there as a distinct entity with a name, a quality and a (hi)story. Whereas the notion of 'space' is rather abstract, mainly future-directed and related 'to instruments and goals, to means and ends' (Lefebvre, 1991 [1974]: 410-411), 'place' has acquired a specific physiognomy by acts and experiences in the past that have left their mark; it is quietly shaped and reshaped by those who inhabit, experience, maintain and transform it in the slow continuity of a lived context. It is important to note that the same geographical area can be referred to either as 'space' or as 'place' according to the intentions and strategies of the speaker. Those who speak of it as 'space' consider it as malleable and changeable, those who consider it as 'place' tend to take the lived environment as a given reality to which they often establish affective bonds. We are dealing here not only with conflicting professional interests but also with cultural frames and programmes that, although they remain implicit, actually carry normative force.

The concepts of space and place can shed new light on sites that are saturated with a history of conflict and violence, producing irreconcilable perspectives, divided memories and contrasting narratives. A paradigmatic case is offered by the Palestinian villages and landmarks that disappeared from the Israeli map after the War of 1948. How are these places forgotten and remembered, and by whom? The political vision of the state of Israel can be framed in terms of 'space': this project is to take possession of a territory without previous markers, a tabula rasa ready for a new inscription. The official version of this perception is 'a land without people for a people without land'. The term 'place', on the contrary, can refer to the attempts to raise awareness within Israeli society to these extinguished and forgotten places, a slow but nevertheless remarkable process of recovery and change of historical sensibility that has grown over the last decade and that can be taken as small but hopeful signs of a shift of attitude that may ultimately lead to the peaceful coexistence of two nations in one territory.

\section{A streetcar named 'desire' - horizontal and vertical connections}

Since 2011, a tramline runs through Jerusalem that connects opposed parts of the city. This route of $14 \mathrm{~km}$ between Pisgat Ze'ev and Herzlberg, linking the Western city with Jewish settlements in the Palestinian part of East Jerusalem, became the topic of an exhibition in the Jewish museum in Hohenems, Austria, in 2015. ${ }^{1}$ Here, visitors were invited on a 'Journey through Yerushalayim Jerusalem - Al Quds' following the route of the tramline by photos to gain an impression of everyday life in this multi-religious and conflictual city inhabited by Jews, Christians and Muslims. 'Each group is living in this city within its own grid, ignoring the others or denying their right to exist, while tourists and pilgrims move though a holy land that is the projection of ancient stories' (Jewish Museum Hohenems, n.d.). The photo exhibition shows auratic sites next to delapidated houses, walls, fences and bleak contested spaces.

With the streetcar, we move through the various 'Jerusalems' that exist next to each other and against each other, often in the same place, mutually obscuring each other. We drive through ruins of past utopias and along numerous monuments to the symbolic and political appropriation of this city. (Jewish Museum Hohenems, n.d.)

In the exhibition, the Jerusalem Light Rail was featured as a 'streetcar named Desire' (Jewish Museum Hohenems), namely, as a symbol for normalcy and carrier of hope for peaceful coexistence. 
I want to compare this urban traffic project that establishes horizontal connections on a daily basis between different areas, communities, perceptions and languages with archaeological projects that create vertical connections in space. In the region of Palestine, many histories have taken place reaching into the distant past. 'Indeed, only a few metres below the surface', writes Eyal Weizman (2012), 'a palimpsest of 5,000-year-old debris, a vertical chronological stack of cultures and lives, narratives or wars and destruction, has been compressed by soil and stone' (p. 40). Most Israeli Archaeologists, however, are less interested in the multi-layered sedimentation of history as such, than in deeper layers of the Bronze and Iron Age that represent the Biblical and Talmudic History of the first four centuries AD. In bypassing Muslim and Ottoman periods, these archaeologists 'short-circuited' history, and, in the mode of nineteenth-century nationalism, constructed for the new State a usable past. The first archaeological endeavours were driven by historical rather than religious interests. By uncovering a past that supplied a history of origin and by directly linking it to the present, Zionists claimed a long and continuous connection to the land (Zerubavel, 1995). Archaeological projects, often carried out by retired generals, were the continuation of warfare with different means, continuing with spades what had started with weapons. Laying bare the Biblical layer of history was a way to claim the land as national and cultural property (Abu El Haj, 2001). Archaeology started in the 1950s and 1960s as a secular nationalist project, today it is continued as a religious nationalist project. What is chosen to be excavated and valued depends on the respective religious myths and national narratives. Amos Elon (1971) has commented on what he called 'a popular pastime and science in Israel': 'Israeli archaeologists, professional and amateurs, are not merely digging for knowledge and objects, but for the reassurance of roots, which they find in the ancient Israelite remains scattered throughout the country' (280).

\section{From place to space: the creation of a tabula rasa after 1948}

The relationship of the Israeli state to the historical layers of its territory is highly ambivalent. It is marked by a strong affective relationship to its distant past and an equally strong aversion to its more recent past that relates to the prehistory of the war of 1948 and the dispossession of Palestinians that followed it. There are two practical options to erase this unwanted past: 'either you dig or you build!' (quoted in Roberts, 2013: 144) After the war of 1948, the victory of the Israeli army and independence from the British Mandate, a new state was founded for which a new territory had to be created into the same geographic landscape. The strategy adopted under these circumstances was not a new invention but an age-old political and cultural practice that can be referred to as 'creative destruction', applying as much to conquest and colonization as to radical forms of modernization (Assmann, 2013). In Israel, the political victory of 1948 marked a radically new beginning, an 'hour zero' with the birth of the Israeli nation, which, for the first time in history since 135 AD, re-gained a political identity by founding its own state. With 1948, a new chronology began for Israeli society. An empty and unshaped ground was needed on which to build a new future, transforming a virgin land and malleable landscape into a coherent space with new landmarks, new names, new designs, new opportunities. After the caesura of the war and the flight and expulsion of Palestinian Arabs from their homes, cities, villages and farms, however, a new starting point had to be constructed that cut off the earlier period of communal living in Palestine, which had to be abruptly and collectively forgotten. Forgetting in this case meant actively demolishing traces, erasing them from view and banning them from conversation. With the foundation of the state, the pre-history that still lingered in the communicative memory of the older generations became an unusable past that had to disappear, with the effect that the victors chose to forget what the defeated emphatically preferred to remember. 
The conquest of the territory was propelled by modern architecture and new settlements often erected on the sites of destroyed Palestinian settlements, a process that is still ongoing. In this way, Israeli history was extensively anchored in buildings, memorials and street names. In addition, an official naming committee took charge of Hebraizing Palestine's geography. 'Dispossession was accompanied by the renaming of the places (that the State) had seized, destroyed, and now recreated' (Pappe, 2006: 225-226). These measures worked together to the effect that the history of the Palestinians was rapidly disappearing from view. Within this neo-colonial frame, remaining traces were easily ignored and neglected. In this case, both 'creative destruction' and 'passive vandalism' (Fisher, 1996: 23) worked together for the Israeli state to transform a place into a new space for the beginning of a new history.

\section{One land and three narratives: Holocaust, War of Independence, Nakba}

In 1948, Israel followed the pattern of Western nations and, as a 'belated nation', created a modern nation state. In the nineteenth century, many new nations were built on the basis of their self-liberation and independence from the repression of larger empires. They also followed the tradition of foundational national myths that all share the same pattern characterized by Peter Novick (1999): 'Collective memory simplifies; sees events from a single, committed perspective; is impatient with ambiguities of any kind; reduces events to mythic archetypes' (p. 4). In other words, in the construction of national memory, mental images turn into icons and narratives become myths, whose most important feature is their persuasiveness and affective power. Such myths remove historical experience from its contexts and re-shape it as a timeless narrative to support the group's selfimage that is passed down from generation to generation. The impact of these narratives does not depend on whether they are true or false (they are, to be sure, always highly selective), but on whether they are needed, that is, whether they serve an important purpose for the group or not. It is only when they are recognized as dysfunctional that they are transformed or replaced with other narratives that are more dialogic and self-critical.

The War of 1948 was a historical event that did not happen in isolation. Within Israel, the war of 1948 is known as the War of Independence, while for Palestinians it is known as the Nakba. The meaning of the War of Independence for the Israelis is intimately tied up with that of the Holocaust that entered its final phase 6 years earlier in Europe. The Holocaust made the Zionist project to find a territory and found a new state in which Jews can live a free and protected life, a matter of utmost urgency and importance. The war of 1948 has two faces: for Jews and Israelis, it is the war of liberation and triumph, while for Palestinians, it is the experience of defeat, forced expulsion, material loss and ongoing trauma. In other words, the War of 1948 is not just another battle that separates victors from losers but one that has become the focus of two foundational narratives. Among the Palestinians, 'the catastrophe' (al nakba), has become 'the key site of (their) collective memory and national identity' (Abu-Lughod and Sa'di, 2007: 4; Slyomovics, 1998). It is not only an individual and collective memory that is transmitted orally across generations, it is also 'reckoned as the beginning of contemporary Palestinian history, a history of catastrophic changes, violent repression, and refusal to disappear' (AbuLughod and Sa'di, 2007: 5).

It is not easy to disentangle the three events that are linked here in an almost Gordian knot. In order to better understand this complex, it is not enough to juxtapose the Holocaust and the Nakba. The events have to be unfolded and extended in time like a telescope in order to get a more inclusive perspective on the interrelation of the three dimensions of this complex: 


\begin{tabular}{lll} 
Holocaust (1933/1942-1945) & War of Independence & Nakba \\
\hline Ihe murder of 6 million Jews by & Tha 'rebirth' of the persecuted & $\begin{array}{l}\text { The expulsion of the Arab } \\
\text { population from their homes } \\
\text { and cities }\end{array}$ \\
\hline $\begin{array}{l}\text { and suffering Jews in their own } \\
\text { state }\end{array}$ &
\end{tabular}

The Jewish Nation is built on two founding myths. One is a narrative of triumph, focusing on the War of Independence and the heroic birth of the new state, the other is a narrative of trauma, focusing on the Holocaust and the 6 million Jews who died at the hands of Germans and their European collaborators. After the Eichmann trial, the Jewish nation understood itself increasingly in terms of this chosen trauma. This made it mandatory for the Israeli society to adopt a strong imperative to remember this history. It also became a cultural mission to inform the world of the mega Nazi crime of the Holocaust, which had succeeded to such a shocking degree because the rest of the world had been watching more or less passively. This memory culture had an immediate impact on Israel's relation to its neighbours. It made it doubly impossible for the Israelis to address and acknowledge the suffering of the Palestinians, first, because the heroic foundational narrative could in no way be tainted by remorse, and second, because the own trauma acted as a protection shield against the trauma of the other. While the historic traces of the trauma of the Holocaust lie outside of the state of Israel, the historic traces of the trauma of the Nakba lie within Israel's territorial limits, where they are neglected, covered up, erased and denied. This is another problematic asymmetry produced by this fatal nexus of opposing perspectives on the same historical events. The abyss between the collective experiences, narratives and interpretations of these entangled memories could not be deeper.

Alon Confino has picked up the two terms 'Holocaust' and 'Nakba' to comment on parallels and differences. He notes that these terms stand for two traumatic foundational events that for two national collectives constitute the most important turning point in their respective histories and victim identities. While the Holocaust, however, is a closed chapter of history for the Jews, the conditions and consequences of the Nakba continue and determine the present. There is yet another asymmetry involved: the Palestinians are not responsible for the fate of the Jews, whereas the Israeli military forces and the ongoing politics of occupation are responsible for the prohibition on the right to return, the further expulsions of Palestinians and the further destruction and appropriation of their property. Acknowledging the Palestinians' tragedy and including it in Israeli memory would be expensive and effective, because it would mean initiating political change and terminating the continuing deprivation. This explains why the Israelis have chosen the alternative of forgetting. Confino describes the inexorable dialectic between forgetting and remembering. In order to daily repress the memory of the Nakba, it has to be again and again brought back into Israeli consciousness:

The Nakba is part of their history, and an important part: they remember the Nakba whether they deny it or relate it in prose or in poetry. The very attempt to erase the memory of the Nakba is the outcome of an immense mobilization of political, economic, and cultural effort. (Confino, 2016) 
The Jewish nation freed itself heroically from the British Empire, but it carries a birth defect: the expulsion of 700,000 Palestinian Arabs. Therefore, two contradictory narratives are connected to the year 1948 that continue to challenge each other: the triumphalist foundational narrative of the new state of Israel and the traumatic narrative of the loss of home, culture, existence and identity of the Palestinians. These historically intertwined events are the subject of two national narratives, each erasing a vital phase of the complex. The Palestinians neglect or deny the prehistory of the conflict (the Holocaust), the Israelis deny or neglect the ongoing aftermath of the conflict (the Nakba and occupation). In this way, two ethnic groups, whose respective views of the other's history are mutually obstructed by blind spots, live on the same land.

There was a short window of opportunity when it seemed that these problems could finally be addressed, bringing the Israelis and the Palestinians closer together. This was in 1998, the year of a double anniversary: 50 years after the foundation of the state of Israel and the Nakba, the Palestinian leadership managed for the first time to place the Nakba on a global agenda. ${ }^{2} \mathrm{~A}$ global appeal of the Palestinian nation was drafted and read on 14 June 1998 by Mahmud Darwish in Ramallah after a commemorative march. It claimed the right to history and sovereignty in a secular, pluralistic and democratic Palestinian state and connected the hope for liberty and peace with the demand for a mutual recognition of the respective historical traumas: 'While we are ready to acknowledge with empathy the inexpressible suffering of the Jews during the horror of the Shoah, we cannot accept that the suffering of our nation is denied or trivialized' (Informationsprojekt Naher und Mittlerer Osten [INAMO], 1998: 72; trans. AA). Two months earlier, a group of Palestinian and Israeli historians had drafted a declaration claiming the right of the Palestinian nation to existence, sovereignty and independence. Paragraph 5 contained the necessity of a mutual recognition of each other's historic trauma.

Antisemitism in Europe, the persecution of the Jews and the Nazi extermination camps belong to the most horrendous crimes and worst forms of barbarism in the history of mankind. But there will not be peace as long as the collective memory of the Palestinians is being erased. Israel has to start to acknowledge its crimes against the Palestinian nation in 1948: massacres, expulsions, destruction and demolition of villages and the exchanging of the names of existing cities and villages. (INAMO, 1998: 73; trans. AA)

On both sides, a promising dialogue started with these 'new historians'. They belonged to a new generation that distanced itself from the generation of the war, ready to break the silence and to self-critically inspect and explode national myths. ${ }^{3}$ Unfortunately, this window of opportunity soon closed and the shutters were again tightly fastened. ${ }^{4}$

\section{Zochrot - memory work in the medium of guided tours}

Next to archaeological digging, active demolishing and passive vandalism, the Israeli State has deployed a fourth strategy to erase the recent past. This is another form of digging as practised in agriculture and foresting. After the Six-Day War in 1967, new national parks were built by the Jewish National Fund all over the country. Ilan Pappe (2006) comments, 'In these forests, Nakba denial is so pervasive, and has been achieved so effectively, that they have become a main area of struggle for Palestinian refugees wishing to commemorate the villages that lie buried beneath them' (p. 227). Green parks with dense forests offering shade are the green lungs and popular recreation areas of the country. What is presented as the pride of the State and Israeli tourism happens to cover up significant historic sites. The Birya Forest, for instance, 'is the largest man-made forest in Israel and a very popular site' (Pappe, 2006: 230). Pappe points out that the villages of Dishon, Alma, Qaddita, Amqa, Ayn al-Zatoun and Biriyya lie buried under the roots of the trees, while the 
website of the site draws attention to the wonders and attractions of nature. In these places, history is converted back into nature. The village of Ayn al-Zatoun, the place of a Massacre in 1948, is advertised to tourists as 'the most attractive ground within the recreational ground as it harbours large picnic tables and ample parking space for the disabled' (Pappe, 2006: 230).

One of the tour guides working in these parks was Eitan Bronstein-Aparicio. Rather than focusing only on nature, he became sensitive to the dimensions of space and place, discovering the history erased in these sites. He made it his project as a guide to mark traces and to recall to memory what had been dismissed and forgotten.

I showed Canada Park in a critical way, how it constructed the landscape for Israelis and neglected, or silenced, the history of the Palestinians there. ... [T] here are hundreds of places in Israel to post signs, not just from 1967, but also from 1948. (Bronstein et al., 2007: 37)

Bronstein became the founder of the Israeli non-governmental organization (NGO) 'Zochrot' in 2002. This group developed a specific plan: in order to raise awareness of the Palestinian Nakba among Israelis, it aimed at making history visible again by focusing on material traces and uncovering the palimpsestic structure of the Israeli landscape. The literal meaning of the Hebrew name of the group is 'to remember' (in the feminine form). One of the NGO's leaders and co-founder, Norma Musih, explained its name in the following way:

Zochrot means the act of remembering in the feminine plural: We remember. In Hebrew, you must choose between masculine and feminine genders. Usually, people choose to speak in the masculine. This is the default. We decided to call it Zochrot because we wanted to promote a different kind of memory. It is not just the memory of wars and the memory of men. It is also a memory of a place that tells other stories, for example, the story of the nakba. (Bronstein et al., 2007: 35)

The organization's logo could not be more symbolic: it is a door lock. This image is highly significant as it was chosen as a counterpart for the keys of the ruined houses that Palestinians have made their most precious relic and icon of commemoration.

To continue Bronstein's struggle against forgetting and erasure, the group regularly offers guided tours in Jerusalem and other cities, a practice that arose over the years as a new cultural memorial practice. These memorial walks are conceived and received not as political demonstrations but as 'performance art' (Roberts, 2013: 227). Yifat Gutman has also underlined the artistic character of these excursions that bring Israelis and Palestinians together to visit demolished and forgotten Palestinian towns and villages (Gutman, 2011, 2016). The idea behind these guided tours and hiking routes is to restore places to memory that were wiped out and dropped from official maps. After visiting a particular place during the tour, the group puts up a sign next to the new Hebrew place name with its former Arabic name. In this way, the memory activists aim to raise awareness for the obliterated Palestinian pre-history of what have become now Israeli cities and villages. In doing so, they also draw attention to the long practice of renaming sites in Hebrew using biblical names that suggest to the inhabitants of the land that Jews are its only legitimate heirs and its indigenous population (Roberts, 2013: 144). These memory walks are designed as individual experiences, emphasizing sensuality and emotionality. Israeli participants listen to the testimonies of Palestinian refugees who share stories, songs, or lectures that stimulate the imagination of the visitors and encourage an involvement with the erased history of the country. These walks aim at creating a transnational memory without being charged with polemical propaganda and an explicit political agenda. They are rather conceived as a soft power strategy to raise awareness for the trauma of a disowned landscape and to change perceptions for the vision of a common future in a shared geographical space (http://zochrot.org/en/booklet/all). 
These excursions, which uncover hidden and erased layers in the palimpsest of the Israeli landscape, have turned out to be quite popular. Up to 100 visitors, Israeli Jews as well as Palestinians who share their stories, turn up for each of these events. Important results of these tours are that they create personal contacts between Israelis and Palestinians in a rather segregated society and that they spread knowledge about the Nakba in the society. These are already remarkable steps, but the question remains how to integrate this memory work into a larger political project. How can the transnational information gained in walking tours pave the way for a new, historically self-critical knowledge that eventually triggers a consequential mental, social and political change? The aim of the declaration of 1998 was a mutual recognition of the trauma of the Holocaust and the trauma of the Nakba as a basis for dialogue, empathy and reconciliation which may contribute ultimately to the peaceful coexistence of two states in one territory.

\begin{tabular}{lllll}
\hline I & II & III & IV \\
\hline Information $\rightarrow$ & Change in awareness & $\rightarrow$ & Recognition $\rightarrow$ & Reconciliation \\
& Knowledge and & Solidarity: establishing & Redress: legal and \\
& personal empathy & & historical truth & political consequences \\
\hline
\end{tabular}

Shelley Berlowitz (2016) has pointed out a shift of policy in the Israeli peace movement. 'The peace agenda used to focus on reconciliation, dialogue and on the acknowledgment of two different narratives - Arab-Palestinian and Jewish-Israeli. Today it focuses on solidarity with the oppressed, on justice, and on truth' (p. 38). This has also affected the agenda of Zochrot as Liat Rosenberg has emphasized: 'We cannot talk about reconciliation when the Nakba is ongoing. We are still in a situation where there is apartheid, constant violations of human rights and 70 percent of the Palestinian community are refugees' (quoted in Berlowitz, 2016: 38). Instead of dialogues, Zochrot organized acts of public witnessing to restore the truth about the Nakba..$^{5}$ These 'Truth Commissions' were staged to 'promote Israeli Jewish society's acknowledgement of and accountability for the ongoing injustices of the Nakba' as a strategy to decolonize the State and its society (Berlowitz, 2016: 38).

The activities of Zochrot may have induced a change of awareness, but the following stages of recognition and reconciliation are not yet within sight. As there is as yet no transnational legal framework to induce change, the process seems currently to be going in the opposite direction. In March 2011, the Knesset passed a 'Nakba law', which further cemented Israel's national myth by penalizing the remembrance of the displacement of Palestinians. Those committed to a critical political awareness and a transformation of the national narrative are now criminalized as enemies of the state who sully the holy values of the nation. In her analysis of the Zochrot group, Yifat Gutman also sees a problem in how these activists perform their tours and lectures only on a local level and do not penetrate to higher levels in the civil society. As long as the members of this NGO do not manage to bring this issue into the centre of the society by winning over important media and educational institutions, it will remain an 'interesting project' without further social or political impact. As Gutman describes the effect of their work, the Zochrot group has achieved in Israel the formation of a counter memory to the official memory of the state. This form of oppositional knowledge-production, however, is in danger of remaining confined to a niche of leftists and nonconformists without challenging established attitudes. Some even fear that this group might end up supporting the status quo instead of unsettling it.

But also this might not be the last word in the process. It is always difficult to foretell changes in mental and historical sensibility, and to predict if and when a nation decides to take a more 
self-critical turn, to revise the attitude of forgetting and to recognize the excluded other. There are already contexts in which symptoms of such a change become visible. Here are two examples, one relating to the institutional frame of the university, the other to the social frame of the family.

Large-scale urban construction projects, which continue to destroy the remnants of Palestinian villages in order to create space for new expensive residences and commercial towers, are no longer praised as manifestations of 'creative destruction', but are currently meeting with harsh criticism from the architecture department at Bezalel University. Michael Jacobson (quoted in Carmon, 2005) made the following comments at a conference:

While many good people, and I among them, were raised on the conception that Tel Aviv was a city born from the sand, it is astounding to discover that the city includes within it a number of sites which until the outbreak of the War of Independence were the sites of Arab villages ... Tel Aviv is not just Herzl, Jabotinsky, Arlosorov, and Ben Gurion, it is also the abandoned Arab villages - Sheikh Muwannis, Jammusin, Salame and Summeil.

Nurit Moskovitch of the architecture department of Tel Aviv University advanced a similar view when her university prepared to extend its compound onto the area of the destroyed Palestinian village Sheikh Muwannis. There, of all places, they planned to erect a new building for the institute of archaeology. In cooperation with Zochrot, she worked out a suggestion of how to incorporate into the planned expansion of the campus 'gaps' that created awareness of the forgotten history of the place. This appeal for memory and its symbolic markers was strongly supported by Moshe Zuckerman (quoted in Carmon, 2005):

If we do not account, symbolically, for the fact that we are here doing science and doing culture and doing education without understanding that we destroyed a culture, destroyed life, destroyed education, destroyed what was here - our education, our culture and our science become something primarily ideological. Memory is not only a matter of moral cleansing, but a principle that if it is not fulfilled makes all of us become barbarians, and those who wish not to be barbarians better start to remember.

My other example is the impressive documentary film Mirror Image by Danielle Schwartz (2013), which has won several awards at international festivals. It is a film about secrets and silences in a three-generation Israeli family, showing the attempt to break this silence about the Nakba in a mutually trustful, highly emotional and cooperative context. In this film, the filmmaker has recorded an interview with her grandparents in which she attempts to resolve the mystery of the origin of a huge mirror that is a striking element among the furniture of her grand-parents' apartment. One thing is clear: the mirror is no heirloom. The grandparents who were able to escape from Europe as young people and fled to Palestine in the early 1930s obviously did not carry large pieces of furniture in their luggage. When asked about this mirror in the setting of a formal 'inquisition', her grandfather tells the story of this mirror as a find made in the Palestinian village Zarnuqa that he reached in 1948, without offering further detail. We also learn that as a child the grandfather grew up close to a Palestinian farm, where he liked to spend time and play with the animals and children. The conversation about the mirror turns into a remarkable communication about the family secret of the whole nation. In this intergenerational exchange covered in the 11 minute film, grandchild and grandparents make a joint effort to find a common language in order to arrive at a shared version of the tabooed story. Was the mirror legally acquired after the war or was it plundered? The words 'plunder', 'take', 'buy' are qualified by question marks and remain side by side as diverse options of the narrative. "Taken' sounds softer than 'plundered', the grandmother intervenes. 'We cannot deny it but we had nothing to do with it' (Schwartz, 2013). In this way, something that had been profoundly forgotten and silenced is restored to communication owing to the 
intervention of a member of the third generation. The film shows this generation's growing interest in the memory of the Nakba and documents a very personal way of breaking the silence.

\section{Conclusion}

Israeli writer Amos (Oz, 1998; trans. AA) once wrote,

If I were in charge at the peace negotiations - be they in Wye, in Oslo, or wherever - I would order the sound technicians to turn off the microphones whenever one of the parties involved starts talking about the past. After all, they are paid to find solutions for the present and the future! (p. 83)

This argument is often repeated: memories lead to a fixation on the past and obstruct the future. ${ }^{6}$ Liberation from a troubled past and regaining a new vision for a shared future is precisely the project of Truth Commissions, which are now regularly used world-wide in the transition to democracy of autocratic regimes. They operate on the opposite conviction that the liberation from a traumatic past begins with an assessment of the historical truth and the recognition of wrongs that were committed. Memory cannot so easily be elided or bracketed, because its transformation into a shared transnational memory has an important role to play in the process of transition and reconciliation. 'This requires willingness on the part of the Palestinians to learn about the Holocaust. ... And it requires willingness on the part of the Jews to learn about the Nakba' (Confino, 2016). If it becomes possible to overcome historical amnesia and to remember a traumatic history of violence from both perspectives, such a shared memory can become the basis for a (more) peaceful future. Tenacious forgetting on one side and frenetic remembering on the other, however, perpetuate the injustice and stabilize the trauma of the victims.

The NGO Zochrot has been criticized by some for not being radical enough by bracketing social and political claims, others have objected to their too radical demands claiming that they polarize the society by uncritically and unpatriotically taking on the memory of the enemy while giving up that of the Israelis. This, however, is not a correct description of their cause. Their aim is in no way to replace their own national memory with that of the Palestinians and thereby undermining the right of existence of the state of Israel and its values. Instead, the contribution of Zochrot to the Israeli state and society lies in drawing attention to questionable founding myths and in correcting obvious gaps in the official national narrative. This commemorative work does not replace one memory with another one but works towards making Israeli memory more self-critical, complex and inclusive. The intention behind it is not to harm one's own nation, but to serve it. This is done by restoring what has been forgotten and erased in the national narrative and by making it more complete.

Long before the spatial turn, back in the 1970s, French historian Henri Lefebvre (1991 [1974]) had warned us: space is 'more than the theatre, the disinterested stage or setting, of action. ... Its role is less and less neutral and more and more active, both as instrument and as goal, as means and as end' (pp. 410-411). The re-imagining of the territory of the state of Israel after 1948 took shape with the transformation of existing historic places into a malleable neutral space to be re-inscribed with a new future and an ancient past. What remains in sight and what is discarded in periods of radical transition depends on social, cultural and political frames. Cicero was right: great is the power of memory that resides in places, and even greater may be the political power that is needed to keep a national memory in place. But this memory is partial and can claim only half of the truth. A transnational memory that includes the perspectives from both sides of a conflict may help to promote mutual understanding and to restore a shared truth of the history of the place that is inherited and inhabited by two nations. 


\section{Notes}

1. 'Endstation Sehnsucht' (A Streetcar Named Desire) was the name of the exhibition at the Jewish Museum Hohenems, presented from May 2015 to February 2016. Commissioned by director Dr. Hanno Loewy and curated by Hannes Sulzenbacher, it showed photographs by Galia Gur Zeev that invited the visitors to open themselves to the multi-national and multi-religious city (Jewish Museum Hohenems, no date).

2. My first contact with the term 'Nakba' dates back to October 1998, when I attended a conference organized by Angelika Neuwirth in Beirut in the German Archaeological Institute (DAI) and had the chance to listen to the reports of renowned Palestinian scholars who told the stories of their lost houses in Jerusalem that had been in the possession of their families for hundreds of years.

3. On the circumstances encouraging these 'new historians', see Morris (2003: 7-9). In the mean time, this author has shifted his position from the left liberal wing to the right nationalist wing.

4. Seventeen years later, 'Holocaust' and 'Nakba' appeared on the title of a collection of essays (Bashir and Goldberg, 2015). The editors, a Palestinian and an Israeli, constellated the terms in the mode of 'multidirectional memory' (Michael Rothberg). In an interview, Bashir Bashir described the terms 'as interconnected in the past, present and future of Israel / Palestine' (The Nakba Files, 2016). For him,

this juxtaposition has a pedagogical and democratizing impact. ... Beyond the question of whether there will be two states or one, a decolonizing commitment to binationalism means that despite being the victims of Zionism we Palestinians must develop an inclusive, humanistic, form of politics that allows us to accommodate Israeli Jews in a democratic venture of togetherness. A productive and joint conversation on the Holocaust and the Nakba is a fundamental pillar of this venture. (The Nakba Files, 2016)

For many Israelis today, bringing the terms Holocaust and Nakba together is still a taboo. What is indeed needed is 'A New Grammar of Conflicting Historical Traumas' (this is the provisional title of Bashir's and Goldberg's book coming out in English). One of the rules of such a grammar was formulated by German historian Bernhard Faulenbach with respect to the memory of the two German dictatorships. Applied to the Holocaust and the Nakba, this rule could read as follows: (1) The Nakba must not relativize the Holocaust. (2) The Holocaust must not trivialize the Nakba.

5. Due to its strong commitment to historical truth, the non-governmental organization (NGO) Zochrot has critiqued and discarded the term 'narrative' as too abstract and relativistic. (I owe this information to Debbie Farber, one of the curators of Zochrot. This essay has also profited from her corrections.) Narratives, however, cannot be so easily dismissed in favor of historical truth, as they have a powerful influence on shaping collective emotions, identity and orientation, thereby also hardening political divisions. To give just one example: The popular Zionist narrative 'from shoah to rebirth' is built into the exhibition of Yad Vashem. As Palestinians point out, this World Holocaust Remembrance Center is also connected to the Nakba, as it is located in close proximity to Deir Yassin, the place of a massacre that occurred in April 1948.

6. For the same reason, Avishai Margalit (in a private conversation) has warned against involving memory in situations of conflict. Memory should only be allowed in a phase of post-conflict reorientation, because, as he argues, it is inflammatory and thus part of the problem and not its solution. Some Israelis like Yehuda Elkana (1988) or Avram Burg (2008) have argued against memory altogether, making a plea for stepping out of the shadow of the Holocaust in order to become free for a new future.

\section{References}

Abu El Haj N (2001) Facts on the Ground: Archaeological Practice and Territorial Self-fashioning in Israeli Society. Chicago, IL: University of Chicago Press.

Abu-Lughod L and Sa'di AH (eds) (2007) Nakba: Palestine, 1948, and the Claims of Memory. New York: Columbia University Press.

Assmann A (2013) Ist die Zeit aus den Fugen? Aufstieg und Niedergang des Zeitregimes der Moderne. Munich: Carl Hanser Verlag.

Bachelard G ([1958] 1994) The Poetics of Space. Boston, MA: Beacon Press. 
Bashir B and Goldberg A (eds) (2015) The Holocaust and the Nakba: Memory, National Identity and JewishArab Partnership. Jerusalem: The Van Leer Jerusalem Institute and Hakibbutz Publishing House (in Hebrew).

Berlowitz S (2016) Unequal equals. How politics can block empathy. In: Assmann A and Detmers I (eds) Empathy and Its Limits. Basingstoke: Palgrave Macmillan, pp. 38-51.

Bronstein E, Norma Musih N and Shah M (2007) A different kind of memory: an interview with Zochrot. Middle East Report 244: 34-38.

Burg A (2008) The Holocaust is Over: We Must Rise from its Ashes. New York: Palgrave Macmillan.

Carmon O (2005) A Palestinian village in the heart of Tel Aviv? Zochrot. Available at: http://zochrot.org/en/ press/50945 (accessed 14 March 2018).

Cicero MT (1931) De Finibus Bonorum Et Malorum [About the Ends of Goods and Evils] (trans. H Harris Rackham). Cambridge, MA: Harvard University Press.

Confino A (2016). The Holocaust and the Nakba (Review of Bashir, Goldberg). H-soz-kult. Available at: https://www.hsozkult.de/publicationreview/id/rezbuecher-25731 (accessed 14 March 2018).

Elkana Y (1988) The need to forget. Ha'aretz, 2 March, posted on 20. August 2014 by the Central University of Budapest Weekly. Available at http://ceuweekly.blogspot.de/2014/08/in-memoriam-need-to-forgetby-yehuda.html (accessed 14 April 2018).

Elon A (1971) The Israelis: Founders and Sons. New York: Hold, Rinehart and Winston.

Fisher P (1996) Local meanings and portable objects: national collections, literatures, music, and architecture. In: Wright G (ed.) The Formation of National Collections of Art and Archaeology. Hanover; London: University Press of New England, pp. 15-27.

Foucault M (1986) Of other spaces. Diacritics 16: 22-27.

Gutman Y (2011) Transcultural memory in conflict: Israeli-Palestinian truth and reconciliation. Parallax 17(4): 64-71.

Gutman Y (2016) Memory Activism: Reimagining the Past for the Future in Israeli-Palestine. Nashville, TN: Vanderbilt University Press.

Harvey D (1989) The Urban Experience. Baltimore, MD: Johns Hopkins University Press.

Informationsprojekt Naher und Mittlerer Osten [INAMO] (1998) 50 Jahre Nakba. Die Erklärung dr Tausend 14/15: 72-73.

Jewish Museum Hohenems (n.d.) A streetcar named desire: a journey through Yerushalayim-Jerusalem-Al Quds. Available at: http://www.jm-hohenems.at/static/uploads/2014/01/folder_endstation_sehnsucht. pdf (accessed 14 March 2018)

Lefebvre H ([1974] 1991) The Production of Space. Oxford: Blackwell.

Morris B (2003) 1948 and After: Israel and the Palestinians. Oxford: Clarendon Press.

Novick P (1999) The Holocaust in American Life. Boston, MA: Houghton Miflin Harcourt.

Oz A (1998) Israelis und Araber: der Heilungsprozeß. In: Trialog der Kulturen im Zeitalter der Globalisierung. Bad Homburg vor der Höhe: Herbert Quandt-Stiftung, pp. 82-89.

Pappe I (2006) The Ethnic Cleansing of Palestine. Oxford: Oneworld Publications.

Roberts J (2013) Contested Land, Contested Memory. Israel's Jews and Arabs and the Ghosts of Catastrophe. Toronto: Dundurn Press.

Said EW (2000) Invention, memory, and place. Critical Inquiry 26(2): 175-192.

Schlögel K (2003) Im Raume lesen wir die Zeit: Über Zivilisationsgeschichte und Geopolitik. Munich; Vienna: Carl Hanser Verlag.

Schwartz D (2013) Mirror Image (Streaming video. Accessible with English subtitles). Available at: https:// vimeo.com/126834647 (accessed 14 March 2018).

Slyomovics S (1998) The Object of Memory: Arab and Jew Narrate the Palestinian Village. Philadelphia, PA: University of Pennsylvania Press.

Soja E (1989) Postmodern Geographies: The Reassertion of Space in Critical Social Theory. London; New York: Verso Books.

The Nakba Files (2016) The Nakba and the Holocaust: a conversation with Bashir Bashir. The Nakba Files. Available at: http://nakbafiles.org/2016/06/27/the-nakba-and-the-holocaust-a-conversation-with-bashirbashir/ (accessed 14 March 2018). 
Tuan Y-F (1977) Space and Place: The Perspective of Experience. Minneapolis, MN; London: University of Minnesota Press.

Weizman E (2012) Hollow Land: Israel's Architecture of Occupation. London; New York: Verso.

Zerubavel Y (1995) Recovered Roots: Collective Memory and the Making of Israeli National Tradition. Chicago, IL: University of Chicago Press.

\section{Author biography}

Aleida Assmann held the chair of English Literature and Literary Theory at the University of Konstanz, Germany (1993-2014). She taught as a guest professor at various universities (Princeton, Yale, Chicago and Vienna). In 2014, she received the Heineken Prize for History and in 2017, the Balzan Prize, together with her husband Jan Assmann. 